\title{
Experience in Evaluating the Project on Research Infrastructure of the Center for Collective Use for the Production of Catalysts
}

\author{
Tatyana S. Novikovaa,b, Aleksandr O. Baranov ${ }^{\mathrm{a}, \mathrm{b}}$ \\ and Maria V. Korolkovab* \\ ${ }^{a}$ Institute of Economics and Industrial Engineering of SB RAS \\ Novosibirsk, Russian Federation \\ ${ }^{b}$ Novosibirsk State University \\ Novosibirsk, Russian Federation
}

Received 18.11.2019, received in revised form 31.03.2020, accepted 13.04.2020

\begin{abstract}
The infrastructural component of Russia's scientific and technological development requires a significant update of the methodology for evaluating the relevant investment projects. The article covers the issue of simultaneous assessment of financial and economic efficiency of research infrastructure projects and justification of the need for government participation for successful implementation of such projects. The suggested methods and models are based on the transition from financial to economic indicators of the project through the adjustment of cash flows, identification of public effects significant for such projects (social, environmental, indirect, price, tax), and allocation of synergistic effects in their composition. These methods and models were tested for the innovative project of the Center for Collective Use "Experimental Catalyst Production", which was proposed by the Institute of Catalysis in 2018 within the framework of the Novosibirsk regional programme "Akademgorodok 2.0". The results show that the stimulation of investment in research infrastructure is justified by a significant excess of the project economic efficiency compared to its financial efficiency and it significantly depends on the choice of an adequate mechanism for government support.
\end{abstract}

Keywords: public-private partnership, financial and economic efficiency, budgetary efficiency, synergistic effects, innovative project, research infrastructure.

The paper is part of the SB RAS Basic Research Programme, Project XI.170-2 "Formation of the foundations of the theory of innovative economics: operational definitions, measurements, models, scientific and technological forecasts and programme", No. AAAA-A17-117022250128-5.

Research area: economics.

\footnotetext{
(C) Siberian Federal University. All rights reserved

* Corresponding author E-mail address: tsnovikova@mail.ru ORCID: 0000-0001-8636-5219 (Novikova); 0000-0001-8597-9788 (Baranov); 0000-0002-6459-6427 (Korolkova)
} 
Citation: Novikova, T.S., Baranov, A.O., Korolkova, M.V. (2020). Experience in evaluating the project on research infrastructure of the center for collective use for the production of catalysts. J. Sib. Fed. Univ. Humanit. Soc. Sci., 13(4), 560-570. DOI: 10.17516/1997-1370-0589.

\section{Problem Statement}

In the conditions of modern scientific and technological development, the interdependence of the participants in the investment activities is sharply increasing, and new types of relationships between them are being formed on the basis of research infrastructure. Institutions for coordination of the activities between the representatives of science, education and business are being established on the bases of the principle of partnership in the form of network infrastructures, centers for collective use and engineering centers formation as well as in the form of sharing unique scientific installations, primarily national and international mega-science ones (Infrastruktura ..., 2016).

Relevant investment projects require adequate methods of evaluating the efficiency and making decisions on the mechanisms for their implementation. Two interrelated problems are characteristic of research infrastructure projects: simultaneous assessment of financial and economic efficiency and justification of the need for the government support of their successful implementation. Financial (commercial) efficiency is regarded as the comparison of project benefits and costs from a perspective of its private participants. Economic (public) efficiency, in its tern, implies a perspective of the society as a whole (Methodical Recommendations for Evaluation..., 2000; Novikova, 2018). As a rule, implementation of such projects is impossible without the government support because of their extremely low (often even negative) level of financial efficiency. The greater the gap between relatively low financial efficiency and high economic efficiency is, the greater the share of the government in the project is. According to the report of the European Commission Directorate-General for Research and Innovation, "public-private partnerships offer an opportunity to translate research into products and to close the gap between academic and industrial research" (Public, 2013: 3).
At first glance, a wide variety of methods for evaluating infrastructure projects, including government support, were created both in Russia and abroad, and they were analyzed in relevant reviews (for example, (Public, 2017; Novikova, 2018: 63-81)). However, in practice, there is an imbalance between the approaches applied in this field. Real methods of evaluating such projects are limited to the analysis of either financial efficiency at the micro level, or economic efficiency at the macro- and mesolevels (Suslov, Buzulutskov, 2014; Malov et al., 2016). For example, the leading Russian Methodology for evaluating the efficiency of a public-private partnership project, a municipal-private partnership project and for determining their comparative advantage ${ }^{1}$ does not contain any requirement for evaluating the economic efficiency (contrary to the provisions of the basic official methodology for the investment projects evaluation (Methodical Recommendations for Evaluation..., 2000)). Instead, the term of socio-economic efficiency was introduced, which was based on qualitative methods only or calculation of particular components that are non-comparable with the results of financial analysis (for example, job creation). This raises serious objections both from theoretical and practical points of view, the reason being the lack of a comprehensive assessment of comparable performance indicators in monetary terms (typical for modern project analysis). This paper introduces the models and methods for simultaneous assessment of financial and economic efficiency of the research infrastructure projects and for quantitative assessment of changes in financial efficiency as a result of various forms of government participation in the project.

Assessment of economic efficiency in accordance with international practice corresponds to the cost-benefit analysis (CBA)

\footnotetext{
1 The methodology was approved by the order of the Ministry of economic development of the Russian Federation No. 894 dated November 30, 2015.
} 
designed for the evaluation of public sector projects, including infrastructure projects (Boardman et al., 2018). In the middle of the last century, the economic aspect of project analysis involved the CBA methods for evaluating private projects in their combination with the financial analysis. This approach was initially developed by international organizations, primarily UNIDO (Dasgupta et al., 1972), the World Bank (Squire et al., 1975; Ward et al., 1991). In Russia, the economic aspect corresponds to the analysis of public efficiency and forms one of the two directions in the project analysis along with the analysis of financial (commercial) efficiency (Methodical Recommendations for Evaluation..., 2000; Novikova, 2018).

In the context of modern scientific and technological development, a number of new methods for economic, social and environmental analysis have appeared in their combination with the financial analysis within government organizations (Guide to Social..., 2012), Structural funds of the European Community (Guide, 2015), international development banks: the European Investment Bank (Economic Appraisal, 2013), the Asian Development Bank (Guidelines, 2017) - and independent funds (Reference Case..., 2019).

Research infrastructure projects are a type of project requiring updated assessment methods and characterized by a combination of low financial and high economic efficiency (Florio et al., 2016). Among the effects of such projects, both direct technological and secondary effects of knowledge diffusion are of particular importance. Their study began in the last century (Grossman et al., 1992) and continued as part of the research of the diffusion of innovations and their associated side effects, as well as indirect and external effects (Llerna et al., 2011). Much of this work has been carried out in the framework of theoretical and empirical studies of spatial economics (Carboni, 2017). In this area, the traditional approach is developing in the context of productivity growth through innovative products and technologies (Gilbert et al., 2018).

\section{Methods for evaluating the projects of research infrastructure}

The financial and economic model of a specific infrastructure project is the key tool for calculations. It facilitates both simultaneous assessment of its financial and economic efficiency at the microeconomic level and detailing the application of various methods for evaluating public effects for different projects (Novikova, 2018). The financial model is typical for evaluating a project from the perspective of private participants. It reflects the relationship between variables, assumptions, and business development factors in the process of project implementation.

The economic model is based on the transition from financial to economic efficiency by adjusting the discount rate and cash flows, depending on the consideration of various factors and calculations of relevant effects. The corresponding relationship of equations for financial and economic cash flows with the characteristic components of infrastructure projects can be presented as follows:

$$
\begin{aligned}
& C F E^{r t}=C F F^{r t}+V^{r t}+W^{r t}- \\
& -E^{r t}+P^{r t}+T^{r t}, t=1, \ldots, T .
\end{aligned}
$$

Notations of cash flows arising from the project implementation in the $r$-th region in the $t$ period:

$C F E^{r t}$ - cash flow balances for the economic analysis;

$C F F^{r t}$ - cash flow balances for the financial analysis;

$V^{r t}$ - cash flows for calculating indirect effects (the result of productivity growth due to technological changes through the use of project products);

$W^{r t}$ and $E^{r t}$ - cash flows for calculating positive external and environmental effects (the result of knowledge diffusion and impact on the environment);

$P^{r t}$ and $T^{r t}$ - cash flows for calculating price and tax effects (with the allocation of financial and economic components in these effects).

It should be noted that among negative externalities these are the most important ecological costs that are taken into consideration. Yet, if the project is aimed at improving the 
environment (for example, utilization of associated petroleum gases), the corresponding component is taken into account in its positive sign.

The level of detailing and the methods of calculating individual effects for various types of infrastructure projects are significantly different. For example, the projects of catalysts implementation are characterized by significant effects already at the first stages of their use, and indirect effects for them can be calculated as an increase in quality and quantity of products in oil refining and petrochemicals in direct dependence on the catalysts implementation. For large-scale projects with complex and significant chains of product cycles, it is necessary to determine indirect and price effects endogenously while using more complex tools of input-output, multiregional, and econometric models.

The suggested model can be used not only to determine the project efficiency, but also to form a financial mechanism for its implementation. The level of financial efficiency can be changed as a result of government support.

The qualitative and quantitative analysis of the consequences of government participation in project implementation is based on the analysis of changes in cash flows and corresponding changes in net present values.

$$
C F F^{r t}=C F F G^{r t}-\Delta T^{r t}-\Delta L^{r t}-\Delta I^{r t}
$$

$C F F^{r t}$ and $C F F G^{r t}$ - cash flows with and without government participation;

$\Delta T^{r t}$ и $\Delta L_{r t^{-}}$changes in tax payments and liquidation value in the case of government participation;

$\Delta I^{r t}$ - investments in the creation of research infrastructure facilities and other budget funded investments.

This formula comprises the components of a possible increase in the project financial efficiency through the investment incentives, including changes in taxes, liquidation value, and private investment. Implementation of each project involves a specific financial mechanism and appropriate reallocation of results among the participants, government participation being taken into account.

\section{Results of evaluating the efficiency of the Center for Collective Use "Experimental Catalyst Production" project}

The project on the Center for Collective Use "Experimental Catalyst Production" creation was initiated in 2018 by the Institute of Catalysis of the Siberian Branch of the Russian Academy of Sciences within the framework of the Novosibirsk regional programme "Akademgorodok 2.0". The project is aimed at solving the problem of a technological gap the Russian catalyst production faces.

To achieve the world class developments in the field of catalysts creation and their industrial implementation, as well as their constant improvement and development of the next generations to maintain their long-term competitiveness there is a need in modern experimental and technological base. The creation of such a base is envisaged in a project of pilot catalysts production with flexible structure. The project provides construction of two buildings for $\mathrm{R} \& \mathrm{D}$ on the pilot production of various catalysts and their debugging with high-pressure installations.

The total amount of investment in the project for the 2019-2030 period are 3692.8 million rubles. Implementation of the project will increase the production of new materials and catalysts in Russia: the total sales volume for the 2023-2030 period, calculated in 2018 prices (including VAT), is estimated at 40,785 million rubles, including hydro-processing catalysts (15,857 million rubles), titanium-magnesium catalysts for olefin polymerization $(8,417$ million rubles), aluminum hydroxide $(2,015$ million rubles), catalysts of dehydrogenation of propane to propylene $(14,496$ million rubles). However, the main results of the project are achieved through the use of catalysts in the oil refining and petrochemical complex of Russia: the increase in sales for the $2023-2030$ period, calculated in 2018 prices (including VAT and excise taxes), is envisaged in the amount of 471,783 million rubles, including $70 \%$ increase in the output of diesel fuel containing domestic hydrotreating and hydrocracking catalysts; $23 \%$ increase in sales of polyethylene and polypropylene due to TMK ("Pipe Metallurgical Co"); $6 \%$ - increase in sales of reforming gas- 
Tatyana S. Novikova, Aleksandr O. Baranov...Experience in Evaluating the Project on Research Infrastructure...

Table 1. Project efficiency: net present value (NPV) in 2019-2030

\begin{tabular}{|l|c|c|c|c|}
\hline \multirow{2}{*}{} & \multicolumn{2}{|c|}{$(\mathrm{r}=0 \%)$} & \multicolumn{2}{c|}{$(\mathrm{r}=12 \%)$} \\
\cline { 2 - 5 } & million rubles & $\%$ & million rubles & $\%$ \\
\hline Financial efficiency & $2,199.3$ & $0.4 \%$ & -524.8 & $-0.3 \%$ \\
\hline Tax effects & $147,305.2$ & $27.9 \%$ & $56,082.4$ & $28.4 \%$ \\
\hline Indirect effects & $378,145.1$ & $71.7 \%$ & $142,107.1$ & $71.9 \%$ \\
\hline Economic efficiency & $527,649.7$ & $100.0 \%$ & $197,664.7$ & $100.0 \%$ \\
\hline Budget effici5ency & $143,805.2$ & $27.3 \%$ & $53,779.7$ & $27.2 \%$ \\
\hline
\end{tabular}

oline due to ball aluminum oxide and $1 \%$ - increase in sales of propylene due to dehydrogenation catalyst. The total sales of new catalysts and additional sales of products due to their introduction into production amounted to approximately 512,568 million rubles.

Thus, besides the initiator, there are two groups of participants that use the project results. These are enterprises producing new catalysts and enterprises in the petrochemical and oil refining industries.

The results of the project efficiency evaluation are shown in Table 1. They are based on a system of discounted indicators (in 2019 prices) and as a percentage of the economic NPV of the project.

The project features a combination of low financial efficiency and high economic efficiency and belongs to the group of socially significant projects requiring support. An important characteristic of the project is an exceptionally high level of economic efficiency. Thus, at a $12 \%$ discount rate, the company's net present value for the 2019-2030 period as a whole will amount to $197,664.7$ million rubles.

As measured by net present value, financial efficiency of the project without budget funding will be negative and will amount to -524.8 million rubles at a $12 \%$ discount rate. As per the analysis of financial efficiency of the project without government support, the internal rate of return for this project is equal to $6,7 \%$.

Fig. 1 presents the iceberg conception. In accordance with it, the results of the project implementation which are visible on the market surface, correspond to its financial efficiency. For the project under consideration, in a situ- ation without government participation, private investors observe overall negative results of its implementation and are not interested in financing it. At the same time, a significant part of economic efficiency is "hidden underwater" and corresponds to the public effects listed above in the equation (1). In this project of developing and implementing the catalysts, the excess of economic efficiency over financial efficiency is mainly due to indirect and tax effects, which is typical for the research infrastructure. These effects are observed in the market, but they are not regarded as the project results by private participants and therefore not taken into account in making the decisions about its financing. The resulting gap between the project economic and financial efficiency is one of the most important demonstration of market failures which is typical for research infrastructure projects and considered as a basis for the government support.

Budget financing in the amount of 3,500 million rubles without discounting (or 2,303 million rubles at a $12 \%$ discount rate) results in a positive net present value of 1,777.9 million rubles at a $12 \%$ discount rate. Changes in the level of financial efficiency as a result of providing support allows private investors to get interested in providing their financial resources and accumulated experience for successful project implementation.

According to Table 1, the key factors that lead to the difference between the financial and economic efficiency of the project under consideration are related to tax and especially indirect effects $(71.9 \%$ to the level of economic efficiency). Budget efficiency also remains high even after budget financing of investments 


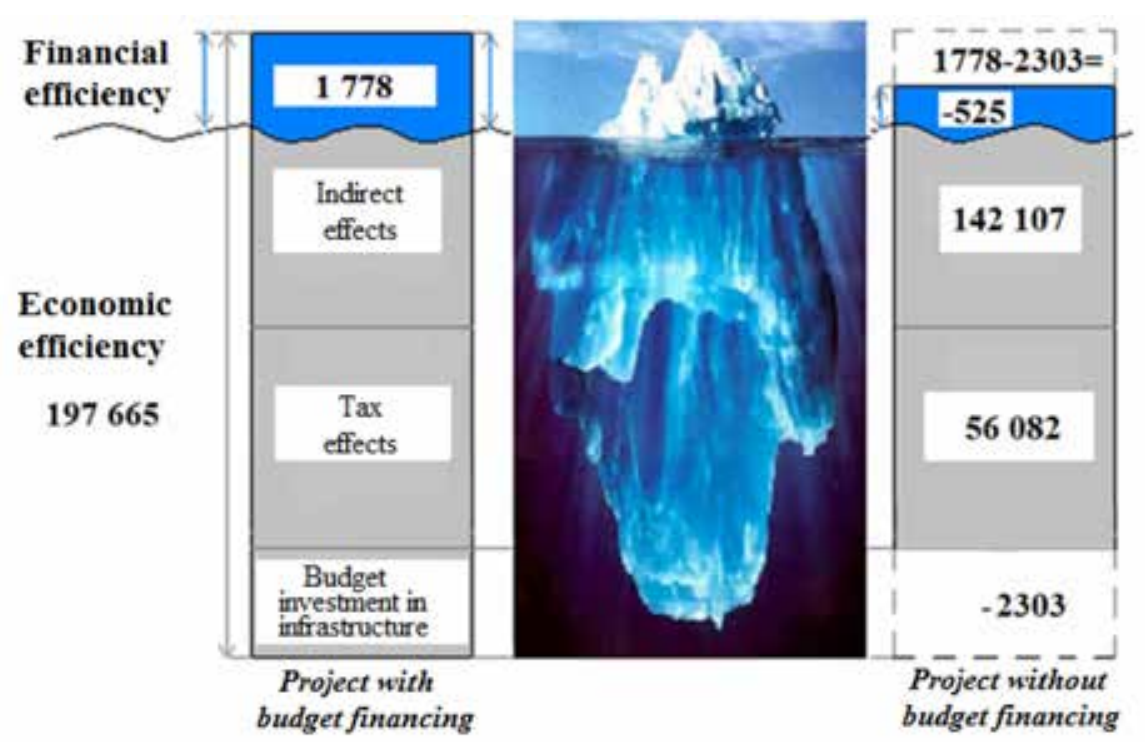

Fig. 1. Illustration of the budget financing impact on the financial efficiency of the Center for Collective Use project (NPV, 2019-2030, million rubles, $r=12 \%$ )

and is $27.2 \%$ of the economic efficiency level. Thus, the proposed PPP mechanism provides a mutually beneficial combination of various participants' interests.

For the 2019-2030 period the government receives net budget revenues in the amount of $53,779.7$ million rubles at a $12 \%$ discount rate, or $143,805.19$ million rubles at calculation without discounting. In other words, taking into account the indirect effects of the project, the investment of one ruble of public investment for the 2019-2030 period will bring 42 rubles of tax revenue to the budget at calculation without discounting and 24 rubles at a $12 \%$ discount rate. Thus, the budget efficiency indicator shows high efficiency of government participation in the project.

\section{Evaluation of synergistic effects of the Center for Collective Use project}

The project under consideration has a fairly complex structure, the structure being typical for research infrastructure. It can be presented by two subprojects.

1. "Creation of the pilot catalysts production" subproject envisages the construction of a building for the pilot catalysts production as well as its provision with the equipment for the production of pilot batches of a wide range of catalysts. R\&D for the development of pilot production technologies, production of pilot batches of catalysts and small pilot batches will be the products of this subproject.

2. "Creation of a catalyst testing center" subproject envisages the construction of a building especially designed for high-pressure installations as well as its provision with the equipment for testing catalysts in high-pressure conditions. $\mathrm{R} \& \mathrm{D}$ on testing the catalysts and developing the processes that require the use of catalysts, creation of test equipment and specialized software, educational services, production of high-tech chemical products will be the products of this subproject.

The subprojects are closely interrelated. Yet, they can also be considered as autonomous projects. So, the task is to justify the need for their implementation in a complex. To do this, it is necessary to identify and evaluate the synergistic effects resulting from the simultaneous construction and operation of two buildings.

The effects are divided into the following groups: 1. Operational efficiency synergy (savings on administrative costs and the ability to use employees in both buildings). 2. Operational growth synergy (cost reduction by combin- 
ing production and testing functions; revenue growth by creating a new product; the ability to test in the second building only other institutes developments in the case without the first building). 3. Investment synergy (savings in joint construction and equipment acquisition; acquisition of capital assets for joint use). 4. Market synergy (providing unique services for the Russian market and the possibility to apply special conditions, such as package offers of products from two projects). 5. Management synergy (use of shared experience or options for subprojects configuration).

The main sources of synergy are identified in the operational sphere, especially in the field of growth synergy, which leads to revenue growth. This is due to the fact that the production of certain types of products requires the implementation of both projects. All expected synergistic effects are taken into account in financial models. Potential sources of synergy in the investment sphere are also identified and taken into account. Potential sources of market and management synergy are determined, but their evaluation has not been carried out due to high uncertainty and inability to make sufficiently justified expert evaluations of their impact.

The calculations have proved the inexpediency of the second subproject implementation separately from the first one. The goal of the second subproject is to create facilities for testing the catalysts manufactured in the course of the first subproject and to develop production processes for their use, since only $10 \%$ of the tested catalysts will be provided by the third-party contractors. Since the second subproject has turned out to be complementary to the first one, all indicators of its efficiency in the absence of the first subproject are assumed to be zero.
The first subproject can be implemented separately from the second one, although the range of the catalysts produced and the technologies developed will become more limited, and testing of catalysts will be carried out at the third-party contractors.

Table 2 shows the evaluation of the synergistic impact on the project financial and economic efficiency. The NPV indicator is calculated at $0 \%$ and $12 \%$ discount rates.

The overall impact of synergy from joint implementation of the subprojects is positive and very significant. It is particularly evident for the economic efficiency - the positive effect of joint project implementation from the point of view of the society can generally amount to approximately 40 billion rubles.

Table 3 shows the distribution of the overall synergistic effect between the project participants. The project initiator (the Institute of Catalysis), the government, as well as enterprises engaged in industrial production of catalysts and production of final products based on them were regarded as participants. The NPV indicators were calculated at $12 \%$ discount rate.

From the total amount of the synergistic effect of 40 billion rubles the project initiator will receive only $2 \%$, the government budget will get $13 \%$, or 5.3 billion rubles, whereas the bulk of the total amount of the synergistic effect will be distributed between the third-party companies using innovative products.

Thus, the simultaneous construction and operation of two buildings by the Institute of Catalysis - those for the pilot production of catalysts and their testing - result in very significant positive synergistic effects. The efficiency of constructing a building for a pilot production only (without a testing building) is significantly lower, whereas constructing a catalyst testing building only is impractical at all. Synergy has

Table 2. The impact of the synergy between the two subprojects on the project efficiency

\begin{tabular}{|l||c|c||c|c|}
\hline \multirow{2}{*}{\multicolumn{1}{|c||}{ million rubles }} & \multicolumn{2}{c|}{ Financial efficiency } & \multicolumn{2}{c|}{ Economic efficiency } \\
\cline { 2 - 5 } & $\mathrm{r}=0 \%$ & $\mathrm{r}=12 \%$ & $\mathrm{r}=0 \%$ & $\mathrm{r}=12 \%$ \\
\hline \hline NPV of the overall project & 2,199 & -525 & 527,650 & 197,665 \\
\hline NPV of subproject 1 & -938 & $-1,317$ & 437,614 & 157,841 \\
\hline Synergistic effect & 3,137 & 793 & 90,036 & 39,823 \\
\hline
\end{tabular}


Tatyana S. Novikova, Aleksandr O. Baranov...Experience in Evaluating the Project on Research Infrastructure...

Table 3. Distribution of synergistic effects among the project participants $(r=12 \%)$

\begin{tabular}{|c|c|c|c|c|c|c|}
\hline & \multicolumn{2}{|c|}{ Complex of projects } & \multicolumn{2}{|c|}{ Project 1} & \multicolumn{2}{|c|}{ Synergistic effect } \\
\hline & $\begin{array}{l}\text { NPV, million } \\
\text { rubles }\end{array}$ & $\%$ & $\begin{array}{l}\text { NPV, million } \\
\text { rubles }\end{array}$ & $\%$ & $\begin{array}{l}\text { NPV, million } \\
\text { rubles }\end{array}$ & $\%$ \\
\hline $\begin{array}{l}\text { Efficiency for the Center for Collective } \\
\text { Use "Experimental Catalyst Production" }\end{array}$ & 1,778 & 0.9 & 985 & 0.6 & 793 & 2.0 \\
\hline Efficiency for the government & 5,380 & 27.2 & 48,458 & 30.7 & 5,321 & 13.4 \\
\hline Efficiency for catalyst manufacturers & 12,245 & 6.2 & 9,180 & 5.8 & 3,066 & 7.7 \\
\hline $\begin{array}{l}\text { Efficiency for the enterprises of } \\
\text { oil refining and petrochemistry }\end{array}$ & 129,862 & 65.7 & 99,218 & 62.9 & 30,644 & 76.9 \\
\hline Total economic efficiency & 197,665 & 100 & 157,841 & 100 & 39,823 & 100 \\
\hline
\end{tabular}

a particularly significant positive impact on both the economic efficiency of the project and its budget efficiency.

\section{Conclusion}

Modern scientific and technological development requires significant changes in evaluating the research infrastructure projects. Thus, it takes into account the growing interdependence of the participants and the corresponding indirect, social, tax, and synergistic effects. As a rule, such projects face a significant gap between low financial efficiency and high economic efficiency. Successful implementation of such projects is possible only with an active participation of the government and the use of various options for public-private partnership mechanisms.

The suggested approach is based on a methodology for comparing the changes in cash flows and corresponding indicators of net present value in the framework of financial and economic analysis, evaluation of both the project efficiency and the efficiency of participation in the project being also taken into consideration. Similar methods can be applied to evaluate the synergistic effects of a complex of interrelated subprojects and to choose their most effective combination. At the same time, the synergistic effects generated by the subprojects are evaluated both in the context of the project financial and economic efficiency and in the context of the efficiency of participation in the project.
The developed methods and models were tested for an innovative project on the Center for Collective Use "Experimental Catalyst Production" creation. The reason for direct government incentives to invest in this research infrastructure in the form of budget funding is a significant difference between a relatively high economic efficiency and a relatively low financial efficiency compared to other projects. In a situation without budget funding this project in its any configuration is characterized by a negative financial efficiency. By providing various forms of support, the government can influence the level of the project financial efficiency and coordinate two types of efficiency. Experimental calculations on evaluating the project on creating the Catalysts Center for Collective Use show that the suggested mechanism of government participation in the project provides a mutually beneficial combination of various participants' interests.

\section{Gratitude}

The authors express their sincere gratitude to Prof. V.A. Yakovlev, Deputy Director of the Institute of Catalysis of the Siberian Branch of the Russian Academy of Science, and N.P. Anfimova, Head of the Department of Scientific-Technical and Innovative Programmes of the Institute of Catalysis of the Siberian Branch of the Russian Academy of Science, for their invaluable assistance in the preparation of this article. 


\section{References}

Ansoff, I. (1999). Novaia korporativnaia strategiia [New corporate strategy]. St. Petersburg, Piter Kom Publishing, 416 p.

Boardman, A.E., Greenberg, D.H., Vining, A.R. and Weimer, D.L. (2018). Cost-Benefit Analysis: Concepts and Practices. Cambridge, Cambridge University Press, 558 p.

Carboni, O. (2017). The Effect of Public Support on Investment and R\&D: An Empirical Evaluation on European Manufacturing Firms. In Technological Forecasting and Social Change, 117(C), 282-295.

Childs, P.D., Ott, S.H., Triantis, A.J. (1998). Capital Budgeting for Interrelated Projects: a Real Options Approach. In Journal of Financial and Quantitative Analysis, 33(3), 305-334.

Damodaran, A. (2005). The Value of Synergy. Available at: https://ssrn.com/ abstract=841486

Dasgupta, A.K., Maglin, S. and Sen, A. (1972). Guidelines for Project Evaluation, Project Formulation and Evaluation Series no 2. New York, United Nations, 383 p.

A Guide to Cost-Benefit Analysis of Investment Projects: Economic Appraisal Tool for Cohesion Policy 2014-2020 (2015). Luxembourg, Publications Office of the European Union, 364 p.

Economic Appraisal of Investment Projects at the EIB (2013). European Investment Bank, 185 p.

Evans, F., Bishop, D. (2015). Otsenka kompanii pri sliianiiah i pogloshcheniiakh. Sozdanie stoimosti $v$ chastnykh kompaniiah [Valuation for M\&A. Building Value in Private Companies]. Moscow, Al'pina Publishing, $332 \mathrm{p}$.

Florio, M. and Sirtori, M. (2016). Social Benefits and Costs of Large-Scale Research Infrastructures. In Techn. Forecasting \& Social Change, 112, 65-78.

Gilbert, P., Bobadilla, N., Gastaldi, L., Le Boulaire, M. and Lelebina, O. (2018). Innovation, Research and Development Management. London, Wiley, $230 \mathrm{p}$.

Grossman, G.M. and Helpman, E. (1992). Innovation and Growth in the Global Economy. Cambridge (MA), MIT Press, 359 p.

Guidelines for the Economic Analysis of Projects (2017). Mandaluyong City, Philippines, Asian Development Bank, $154 \mathrm{p}$.

Guide to Social Return on Investment (2012). The SROI Network. UK Cabinet Office. Available at: http://www.socialvalueuk.org/resources/sroi-guide

Gupta, D., Gerchak, Y. (2002). Quantifying Operational Synergies in a Merger/Acquisition. In Management Science, 48 (4), 517-533.

Infrastruktura issledovanii i razrabotok, bol'shaia nauka i mezhdunarodnoe nauchno-tehnologicheskoe sotrudnichestvo [Research and development infrastructure, large science and international scientific-technological cooperation] (2016). Moscow, Natsional'nyi issledovatel'skii universitet «Vysshaia shkola ekonomiki» [National Research University Higher School of Economics], 43 p.

Knoll, S. (2008). Cross-Business Synergies: A Typology of Cross-Business Synergies and a Mid-Range Theory of Continuous Growth Synergy. Gabler Verlag, 416 p.

Korolkova, M.V. (2019). Otsenka sinergicheskikh effektov, voznikaiushchikh v komplekse investitsionnykh proektov [Assessing the synergy effect arising in a set of investment projects]. In Finansy i Kredit [Finances and Credit], 25 (7), 1680-1698.

Llerna, P., Matt, M. and Trenti, S. (2011). Institutional Arrangement of Technology Policy and Management of Diversity: the Case of Digital Switching System in France and Italy. In Innovation Policy in a Knowledge-Based Economy. New York, Springer, 380 p.

Malov, V.Iu., Melent'ev, B.V., Ionova, V.D. (2016). Transportnyi kompleks v ekonomike strany: proektnyi podkhod [Transport complex in national economy: project approach]. In Opyt i puti resheniia nauchnykh problem vodnogo transporta Sibiri i Dal'nego Vostoka [Experience and solutions of scientific problems of water transport of Siberia and the Far East]. Novosibirsk, Izd-vo Sib. gos. un-ta vodnogo transporta, 35-56.

Methodical Recommendations for Evaluation of the Efficiency of Investment Projects (2000). Moscow, Economics, $422 \mathrm{p}$.

Nakagawa, M. (2007). Synergies and Investment Decisions. In Economics Bulletin, 7, 1-11. 
Novikova, T.S. (2018). Otsenka investitsionnykh proektov v usloviiakh sovremennogo NTR [Evaluation of Investment Projects in Conditions of Contemporary Science and Technology Development]. Beau Bassin, LAP LAMBERT Academic Publishing RU, 572 p.

Public Private Partnership in Life Sciences Research and Innovation under Horizon 2020 (2013). Brussels, European Council, 58 p.

Public Private Partnerships Reference Guide. Version 3.0. (2017). World Bank Group, 232 p.

Reference Case Guidelines for Benefit-Cost Analysis in Global Health and Development (2019). Bill \& Melinda Gates Foundation. Available at: https://sites.sph.harvard.edu/bcaguidelines/

Squire, L. and van der Tak, H.G. (1975). Economic Analysis of Projects. Baltimore, John Hopkins University Press, 153 p.

Suslov, N.I., Buzulutskov, V.F. (2014). Modelirovanie potentsial'nykh effektov ot utilizatsii teplovoi energii s ispol'zovaniem instrumentariia OMMM-TEK [Modeling of potential effects from utilization of thermal energy using the OMMM-TEK tools]. In Vestnik Novosibirskogo gosudarstvennogo universiteta. Seriia: Sotsial'no-ekonomicheskie nauki [Bulletin of Novosibirsk State University. Series: Social and Economic Sciences], 14 (4), 15-33.

Ward, W.A. and Deren, B.J. (1991). The Economics of Project Analysis: A Practioner's Guide. Washington DC, EDI, $310 \mathrm{p}$.

Yescombe, E.R. (2013). Public-Private Partnerships: Principles of Policy and Finance. Oxford, Elsevier Science, $190 \mathrm{p}$. 


\title{
Опыт оценки проекта
}

\section{научно-исследовательской инфраструктуры ЦКП \\ по производству катализаторов}

\author{
Т.С. Новикова ${ }^{\mathrm{a}, 6}$, А.О. Баранов ${ }^{\mathrm{a}, \mathrm{6}}$, \\ М.В. Королькова \\ ${ }^{a}$ Институт экономики \\ и организации промышленного производства СО РАН \\ Российская Федерачия, Новосибирск \\ ${ }^{6}$ Новосибирский государственныий университет \\ Российская Федеращия, Новосибирск
}

\begin{abstract}
Аннотация. Данная статья посвящена проблеме одновременной оценки финансовой и экономической эффективности проектов исследовательской инфраструктуры и обоснованию необходимости государственного участия для успешной реализации таких проектов. Предлагаемые методы и модели основаны на переходе от финансовых к экономическим показателям проекта на основе корректировки потоков денежных средств с выделением значимых для таких проектов общественных эффектов (косвенных, налоговых, эффектов перелива знаний, социальных, экологических, ценовых), а также выделения в их составе синергических эффектов. Предложенные методы и модели были апробированы для инновационного проекта Центра коллективного пользования «Опытное производство катализаторов», который был предложен Институтом катализа в 2018 году в рамках региональной программы «Новосибирский Академгородок $2.0 »$. Полученные результаты показывают, что стимулирование инвестиций в исследовательскую инфраструктуру обосновано значительным превышением экономической эффективности проекта по сравнению с финансовой эффективностью и существенно зависит от выбора адекватного механизма государственного участия в проекте.
\end{abstract}

Ключевые слова: финансовая и экономическая эффективность, бюджетная эффективность, синергические эффекты, инновационный проект, научноисследовательская инфраструктура.

Статья выполнена в рамках Программы фундаментальных научных исследований СО РАН, Проект XI.170-2 «Формирование основ теории инновационной экономики: операциональные определения, измерения, модели, научно-технологические прогнозы и программы», № AАAА-А17-117022250128-5.

Научная специальность: 08.00.00 - экономические науки. 